\title{
Intense FDG Uptake around the Inguinal Surgical Mesh 5 Years after Operation: Case Report and Review of the Literature
}

\author{
Inguinal Cerrahi Yama Etrafinda Ameliyattan 5 YIl sonra Yoğun FDG Tutulumu: \\ Olgu Sunumu ve Literatür Özeti
}

\author{
Tatiana Bahçeci, Gül Nihal Nursal, Mehmet Aydın \\ Başkent University, Department of Nuclear Medicine, Ankara, Turkey
}

\begin{abstract}
We present the case of a 40-year-old man who underwent a FDG PET/CT study for restaging of renal cell carcinoma treated with left nephrectomy, for suspected metastasis in lung and retroperitoneal lymph nodes. The patient had a history of left inguinal hernia repair with implantation of mesh prosthesis 5 years ago. PET/CT image revealed linear intense FDG uptake in left inguinal region most likely corresponding to a persistent foreign body reaction. In this article, a case with an intense FDG uptake around mesh prosthesis after many years was reported, and a summary of the literature about surgical mesh and foreign body reaction causing FDG uptake was reviewed. (MIRT 2012,21:35-37)
\end{abstract}

Key words: Positron emission tomography, fluorodeoxyglucose F-18, surgical mesh, foreign-body reaction

\section{Özet}

Sol nefrektomize ve renal hücreli karsinoma tanılı, 40 yaşında erkek hastada akciğer ve retroperitoneal metastaz şüphesi ile yeniden evreleme amacıyla PET/BT yapıldı. Hastanın PET çalışmasından 5 yıl önce cerrahi yama (mesh) kullanılarak sol inguinal fıtık ameliyatı hikâyesi mevcuttu. PET/BT görüntüleri sol inguinal bölgede lineer yoğun FDG tutulumu gösterdi ve öncelikle bunun yabancı cisim reaksiyonuna ait olduğu düşünüldü. Bu yazıda, ameliyattan yıllar sonra bile cerrahi yama etrafında yoğun FDG tutulumu gösteren bir olgu sunuldu ve bu konudaki literatür özeti verildi. (MIRT 2012,21:35-37)

Anahtar kelimeler: Pozitron emisyon tomografi, fluorodeoksiglukoz F-18, cerrahi ağ, yabancı cisim reaksiyonu

\section{Introduction}

Over the last few years, 18F-fluorodeoxyglucose (FDG) $\mathrm{PET} / \mathrm{CT}$ has become increasingly widespread in the management of various types of cancer patients. Although FDG PET/CT has a high accuracy especially in certain clinical settings, FDG as a glucose analogue is a very sensitive but less specific tracer (1) Not only most tumor cells, but inflammatory cells have increased FDG uptake, which cause sometimes false positive results in cancer patients. One of these unexpected situations is surgical mesh, which causes FDG uptake corresponding to foreign body reaction or infection $(2,3,4)$. In this article, a patient with intense FDG uptake around his left inguinal surgical mesh was reported and the review of the literature was presented.

\section{Case Report}

A 40-year-old man underwent a FDG PET/CT study for restaging of renal cell carcinoma for suspected metastasis 
in lung and retroperitoneal lymph nodes. He was treated with left nephrectomy two months ago. PET images were acquired 60 minutes after intravenous injection of 333 $\mathrm{MBq}(9 \mathrm{mCi}) \mathrm{FDG}$ nn PET/CT scanner (GE Discovery STE 8). PET images showed a slight FDG uptake over the left subcostal incision line due to recent left nephrectomy scar and an unexpected intense FDG uptake on left inguinal region (Figure 1a, b, c; Figure 2a, b). From the patient's clinical history, we learned that he had a left inguinal hernia repair with implantation of mesh prosthesis 5 years ago. By now, the patient had no pain but a serous leakage from left inguinal region without any infection signs. This linear intense FDG uptake in left inguinal region suggested a persistent foreign body reaction. In this patient, PET/CT showed physiological FDG uptake on the rest of the body without any metastases.

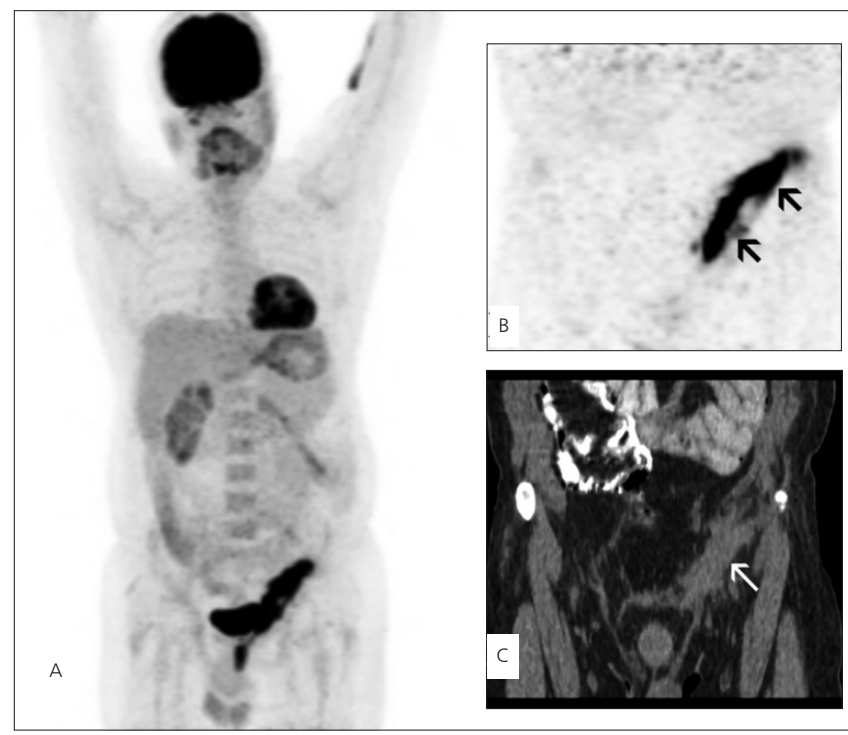

Figure 1. A, B, C. Maximum intensity projection (MIP) images (A) and coronal PET image (B) show increased FDG uptake on left inguinal region (arrows). Coronal CT image $(C)$ demonstrates soft tissue thickening (white arrow)

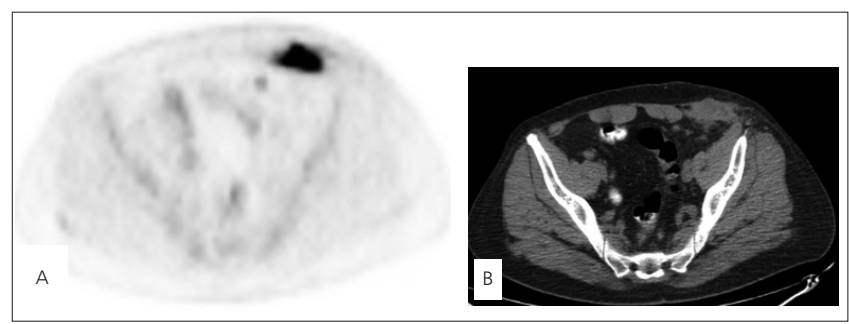

Figure 2. A, B. Axial PET image of the pelvic region shows an intense FDG uptake at left anterior abdominal wall corresponding to repaired hernia region with surgical mesh implant, with a maximum standardized uptake value (SUV) of 17.5. Axial CT image demonstrates soft tissue thickening including a hypodense area

\section{Literature Review and Discussion}

FDG PET/CT is widely used for evaluation of various types of cancer patients. FDG is a glucose analogue and a non-specific agent for malignancy. Increased FDG uptake can be seen not only in malignant lesions, but also in benign inflammatory processes. Active granulomatous processes, infectious diseases and inflammatory reactions are well-known false positive causes for cancer patients (1).

Surgical mesh is a woven fabric used for chest wall reconstruction, strengthening tissues; provide support for internal organs, and to treat surgical or traumatic wounds. Surgical mesh is often used in hernia repair and is placed on or under the damaged area in the abdomen. As with any surgical implant, some complications can occur, including infection, inflammation and tissue damage (5).

FDG uptake in surgical mesh has been reported previously $(2,3,4,6,7)$ In the literature, there are some cases that show FDG uptake around mesh prosthesis due to persistent foreign body reaction that occurred up to 10 and 25 years after implantation $(2,3,4)$ It can be considered as a pitfall of $\mathrm{PET} / \mathrm{CT}$, such a source of false positive results should be carefully avoided by reviewing the patient's history. In our case, an intense FDG uptake in the absence of infection strongly suggested persistent foreign body reaction. In a rat model study, immunohistochemical analysis revealed macrophage predominance cell type in the mesh prostheses-dependent chronic inflammatory infiltrate (6).

In literature, there are several cases that show FDG uptake corresponding to foreign body reaction. Such uptake has been reported in conjunction with mesh and teflon prostheses, breast silicone, catheter, arthroplasty, and the other foreign bodies $(8,9,10,11,12,13,14,15,16,17$, $18,19,20,21,22,23,24,25)$. The FDG uptake mechanism is considered as a foreign body granulomatous reaction with inflammation and fibrosis. Careful correlation with the patient's history and correlative imaging techniques such as $\mathrm{CT}$ are recommended to avoid misdiagnosing malignancy.

In summary, this case report shows a very intense FDG uptake around mesh prostheses suggesting foreign body reaction, occurred 5 years after inguinal hernia repair. We have reviewed FDG uptake in mesh-induced foreign body reaction with this case report, to emphasize the importance of the clinical history during interpretation of PET/CT studies.

\section{References}

1. Mittra E, Quon A. Positron emission tomography/computed tomography: the current technology and applications. Radiol Clin North Am 2009;47:147-160.

2. Yilmaz M, Sevinc A, Aybasti N, Celen Z, Zincirkeser S. FDG Uptake in Abdominal Mesh Implant on FDG PET/CT. Clin Nucl Med 2008;33:351-352. 
3. Koljevic-Markovic A, Orcurto MV, Doenz F, Delaloye AB, Prior JO. Persistent FDG Uptake Around an Inguinal Mesh Prosthesis 25 Years After Implantation. Clin Nucl Med 2007;32:242-243.

4. Aide N, Deux JF, Peretti I, Mabille L, Mandet J, Callard P, Talbot JN. Persistent foreign body reaction around inguinal mesh prostheses: a potential pitfall of FDG PET. AJR Am J Roentgenol 2005; 184:1172-1177.

5. Schumpelick V, Fitzgibbons RJ. Risk for infection. In: Schumpelick V, Fitzgibbons RJ (eds). Hernia Repair Sequelae. 1st Edition. Berlin, Springer-Verlag, 2010;97-143.

6. Rosch $R$, Junge $K$, Schachtrupp $A$, Klinge $U$, Klosterhalfen $B$, Schumpelick V. Mesh implants in hernia repair: inflammatory cell response in a rat model. Eur Surg Res 2003;35:161-166.

7. Martínez-Lage JF, Ferri Niguez B, Almagro MJ, Rodriguez MC, Pérez-Espejo MA. Foreign body reactions causing spinal cord tethering: a case-based update. Childs Nerv Syst 2010;26:601606.

8. Miyake KK, Nakamoto Y, Mikami Y, Ishizu K, Saga T, Higashi T, Togashi K. F-18 FDG PET of foreign body granuloma: pathologic correlation with imaging features in 3 cases. Clin Nucl Med 2010;35:853-857.

9. Kim SW, Shin HC, Kim IY, Baek MJ, Cho HD. Foreign body granulomas simulating recurrent tumors in patients following colorectal surgery for carcinoma: a report of two cases. Korean J Radiol 2009:10:313-318.

10. $\mathrm{Yu} J \mathrm{Q}$, Milestone BN, Parsons RB, Doss $M$, Haas N. Findings of intramediastinal gossypiboma with F-18 FDG PET in a melanoma patient. Clin Nucl Med 2008;33:344-345.

11. Nakajo M, Jinnouchi S, Tateno R, Nakajo M. 18F-FDG PET/CT findings of a right subphrenic foreign-body granuloma. Ann Nucl Med 2006;20:553-556.

12. Chen MY, Ng KK, Ma SY, Wu TI, Chang TC, Lai CH. False-positive fluorine-18 fluorodeoxy-D-glucose positron emission tomography imaging caused by retained gauze in a woman with recurrent ovarian cancer: a case report. Eur J Gynaecol Oncol 2005;26:451-453.

13. Yuh-Feng T, Chin-Chu W, Cheng-Tau S, Min-Tsung T. FDG PET CT features of an intraabdominal gossypiboma. Nucl Med 2005; 30:561-563.

14. Hsu CH, Lee CM, Lin SY. Inflammatory pseudotumor resulting from foreign body in abdominal cavity detected by FDG PET. Clin Nucl Med 2003:28:842-844.
15. De Winter F, Huysse W, De Paepe P, Lambert B, Poffyn B, Dierckx R. High F-18 FDG uptake in a paraspinal textiloma. Clin Nucl Med 2002;27:132-133.

16. Ho L, Wassef $H$, Seto J. FDG PET/CT imaging in granulomatous changes secondary to breast silicone injection. Clin Radiol 2010;65: 659-661

17. Chen CJ, Lee BF, Yao WJ, Wu PS, Chen WC, Peng SL, Chiu NT. A false positive F-FDG PET/CT scan caused by breast silicone injection. Korean J Radiol 2009;10:194-196.

18. Lim ST, Jeong HJ, Kim DW, Yim CY, Sohn MH. F-18 FDG PET-CT findings of intraperitoneal carbon particles-induced granulomas mimicking peritoneal carcinomatosis. Clin Nucl Med 2008;33:321-324.

19. Schouten LR, Verberne HJ, Bouma BJ, van Eck-Smit BL, Mulder BJ. Surgical glue for repair of the aortic root as a possible explanation for increased F-18 FDG uptake. J Nucl Cardiol 2008:15:146-147.

20. Delank KS, Schmidt M, Michael JW, Dietlein M, Schicha H, Eysel P. The implications of 18F-FDG PET for the diagnosis of endoprosthetic loosening and infection in hip and knee arthroplasty: results from a prospective, blinded study. BMC Musculoskelet Disord 2006;7:20.

21. Kisielinski K, Cremerius $U$, Reinartz $P$, Niethard FU. Fluordeoxyglucose positron emission tomography detection of inflammatory reactions due to polyethylene wear in total hip arthroplasty. J Arthroplasty 2003;18:528-532.

22. Harrigal C, Branstetter BF 4th, Snyderman $\mathrm{CH}$, Maroon J. Teflon granuloma in the nasopharynx: a potentially false-positive PET/CT finding. AJNR Am J Neuroradiol 2005;26:417-420.

23. Modi D, Fulham MJ, Mohamed A, Havas TE. Markedly increased FDG uptake in a vocal cord after medialization with Teflon: PET/CT findings. Clin Nucl Med 2005;30:45-47.

24. Bhargava P, Kumar R, Zhuang H, Charron M, Alavi A. Catheterrelated focal FDG activity on whole body PET imaging. Clin Nucl Med 2004;29:238-242.

25. Nguyen $M$, Varma $V$, Perez $R$, Schuster DM. CT with histopathologic correlation of FDG uptake in a patient with pulmonary granuloma and pleural plaque caused by remote talc pleurodesis. AJR Am J Roentgenol 2004;182:92-94. 